\title{
59. Inci Sözlük'te yabancı dil olarak Fransızca: Fransızca başlıklı girdilerin Web tabanlı söylem çözümlemesi yoluyla incelenmesi
}

Cansu AVCI'

\section{Erdoğan KARTAL ${ }^{2}$}

\begin{abstract}
APA: Avcı, C.; Kartal, E. (2021). İnci Sözlük’te yabancı dil olarak Fransızca: Fransızca başlıklı girdilerin web tabanlı söylem çözümlemesi yoluyla incelenmesi. RumeliDE Dil ve Edebiyat Araştırmaları Dergisi, (24), 1049-1066. DOI: 10.29000/rumelide.995488.
\end{abstract}

$\ddot{O} \mathbf{z}$

Osmanlı'dan Cumhuriyet'e kadar uzanan tarihi süreçte devletlerarası askeri, siyasal, kültürel ve ekonomik ilişkiler dil üzerinde de etkisini göstermiştir. Değişik zamanlarda dünya çapında yayılmacı bir güç haline gelen ve her alanda söz sahibi olan başta İngiltere, Fransa ve Amerika Birleşik Devletleri gibi güçlü devletler bu süreçte kendi dillerini yaymak için de çeşitli girişimlerde bulunmuşlardır. Bu bağlamda gerek siyasi, askeri ve ekonomik gerekse de sosyal ve kültürel anlamda dünyanın en önemli dillerinden biri olarak kabul gören Fransızca, Türkiye tarihinin belli dönemlerinde, özellikle 17. yüzyıldan başlayarak 20. yüzyılın ikinci yarısına kadar birinci yabancı dil olma ayrıcalığını korumuştur. Asırlar boyu Türklerin Fransızlarla, dolayısıyla Fransızcayla olan sosyal ve kültürel etkileşimleri neticesinde bu dile özgü doğru ya da yanlış pek çok bilgi, görüş, düşünce ve algıya sahip olmalarına neden olmuştur. Bu çalışmada, Türkiye'de sosyal medyanın en çok kullanılan platformlarından biri olan İnci Sözlük’te üretilen "Fransızca" algısının incelenmesi amaçlanmaktadır. Kurulduğu günden (25 Aralık 2006) 2020 yılının sonuna kadar sözlüğe “Fransızca” başlığı altında girilen 95 girdi (entry)'nin tamamı derlenerek çalışmanın bütüncesi oluşturulmuştur. Nitel araştırma yaklaşımlarından fenomenolojik desene göre yapılandırılan çalışmada girdiler ise Web tabanlı söylem çözümlemesi (Herring, 2004) yoluyla değerlendirilmiştir. Sonuç olarak; sözlükte "Fransızca" başlı̆̆ı altında yer alan girdilerin, genelde sözlük yazarlarının kendi kişisel deneyim ve fikirlerine ya da kulaktan dolma kimi bilgilere dayandığı görülmektedir. Buna istinaden, Fransızcayla ilgili kimi zaman yansız (nötr), kimi zaman da olumlu ya da olumsuz düşüncelere sahip oldukları, Fransızcanın sesletimsel özelliklerinden dolayı zaman zaman bu dili alaya aldıkları ve kimi kelimelerinin okunuşlarını Türkçe ile bağdaştırarak cinselliği çağrıştırdığı yönünde yorumlarda bulundukları sonucuna varılmıştır.

Anahtar kelimeler: Fransızca, İnci Sözlük, entry, web tabanlı söylem çözümlemesi, fenomenoloji

\section{French as a foreign language in The Dictionary of Inci's: The research of entries entitled French via Web-based discourse analysis}

\author{
Abstract \\ From the long historical period of Ottoman to the Turkish Republic, the foreign affairs of politics, \\ culture, military and economy have also effects on the language. Some countries which have become \\ superpower strengths in the world in different times mainly England, USA and French attempted to \\ 1 Doktora, Bursa Uludağ Üniversitesi, Eğitim Bilimleri Enstitüsü, Fransız Dili Eğitimi Bilim Dalı (Bursa, Türkiye), \\ cansuavci@gmail.com, ORCID ID: oooo-0oo1-9336-8127 [Araştırma makalesi, Makale kayıt tarihi: 08.06.2021-kabul \\ tarihi: 20.09.2021; DOI: 10.29000/rumelide.995488] \\ Prof. Dr., Bursa Uludağ Üniversitesi, Eğitim Fakültesi, Fransız Dili Eğitimi ABD (Bursa, Türkiye), \\ ekartal@uludag.edu.tr, ORCID ID: 0000-0002-9836-5221. \\ Adres | Address \\ RumeliDE Dil ve Edebiyat Araştırmaları Dergisi $\quad$ RumeliDE Journal of Language and Literature Studies \\ Osmanağa Mahallesi, Mürver Çiçeği Sokak, No:14/8 Osmanağa Mahallesi, Mürver Çiçeği Sokak, No:14/8 \\ Kadıköy - ÍSTANBUL / TÜRKIYE 34714 Kadıköy - ISTANBUL / TURKEY 34714 \\ e-posta: editor@rumelide.com e-mail: editor@rumelide.com, \\ tel: +90 505 7958124, +90 216773 o 616 phone: +90 505 7958124, +90 2167730616
}


spread their language in this period. In this case, the language of French which was accepted as the most significant languages of the world both politically, military, economically and socially and culturally has maintained its prestige in Turkish history especially starting from 17th century to the second half of 2oth century. For centuries, the social and cultural interaction of the Turks and the French with each other accordingly with French has led them to possess plenty of accurate or inaccurate information, idea, view and perception which are peculiar to French. In this research, it is aimed to analyze the perception of "French" produced in the dictionary of INCI's that is one of the most commonly used platforms of social media in Turkey. Since its foundation (December, 25, 2006) to the end of 2020, this study has composed its corpus by collecting the whole 95 entries entitled French in this dictionary. In this analysis which was conducted according to the phenomenological model of the qualitative research approach, entries are assessed by web-based discourse analysis. (Herring, 2004) As a result, the entries under the title of French generally seem to be based on the personal experiences and views of dictionary authors or some information which is hearsay. Therefore, it has been deduced that they have sometimes objective and in favor or against ideas, they also tease about the language due to its special articulation and they comment that it recalls sexuality via adapting Turkish language with the pronunciation of some words.

Keywords: French, İnci Dictionary, entry, web-based discourse analysis, phenomenology

\section{Giriş}

İnsanlar arasındaki yazılı ya da sözlü iletişim aracı olarak tanımlanan dil, aynı zamanda toplumsal bir kurumdur. Toplumun tüm kesimleri sürekli gelişim gösteren bu kurumun sayesinde birbirleriyle duygu, düşünce ve bilgi alişverişinde bulunurlar. Özellikle teknolojik buluşlar sayasinde sürekli gelişen ve değişen yaşam şartları beraberinde, insanın kendisinden farklı olanı anlama ve tanıma gayretini daha da artırmıştır. Böylelikle her geçen gün daha çok bilgiye gereksinim duyan insan için çok yönlü ve sürekli iletişim durumu bir bakıma zorunlu bir hal almıştır. Bu zorunluluk da âdeta insanları kendi anadillerinin dışında başka dil ve dilleri öğrenmeye ve konuşmaya yönlendirmiştir.

Geçmişten günümüze Türklerin farklı dönemlerde farklı dünya dilleri ile bağlanlılarının olduğundan söz edilebilir. Bu bağlantılarda bilim, teknoloji, siyasi ve askeri güç, din gibi kimi etmenlerin belirleyici bir role sahip olduğu görülmektedir. Eski Çağda, tam olarak Roma İmparatorluğu döneminde Grekçe ve Latince, Orta Çă̆'da ise Latince ve Arapça baskın olmuştur. Günümüzde ise İngilizce tüm dünyada olduğu gibi Türk toplumu nezdinde en yaygın uluslararası dil olarak kabul görmektedir. Türkiye'nin Fransızcıyla olan uzun tarihsel geçmişine bakıldığında da Türkler ile Fransızların birbirlerini Haçh Seferleri (1096-1272)'nden bu yana sanat, edebiyat, kültür, ticaret ve sosyal alanlarda etkiledikleri görülmektedir. Gökmen (2017: 2-3) göre, 16. yüzyıldan başlayarak Türk-Fransız ilişkilerinin ticari, siyasi ve askeri alanlarda gelişmesiyle birlikte Fransız dili ve kültürü Osmanlı topraklarında etkisini göstermeye başlamış ve bu sayade İstanbul ve İzmir'de yabancı dil öğretim etkinliği kapsamında Fransız okulları açılmıştır. Sonraki yıllarda Paris'teki matbaalar ve kütüphaneler örnek alınarak İstanbul'da bir basımevi kurulmuş, önce bir Türkçe-Fransızca sözlük ardından da Fransızca gramer kitabı basılmıştır. 17. yüzyılda ise askeri alanda güç kazanmak için Fransa'nın bilim ve tekniği model alınmıştır. 18. yüzyıl askeri alanda gelişmelerin görüldügü yıldır. Fransa'dan çok sayıda öğretmen, mühendis ve subayların yaptıkları çalışmalar Türkçeye çevrilir ve okullarda Fransızca birinci yabancı dil olarak okutulmaya başlanır. Tüm bu Batılılaşma çabaları göz önüne alındığında Osmanlı İmparatorluğu'nda iletişim bağlamında Fransızcanın yabancı bir dil olarak ayrıcalıklı bir yere sahip olması hiç de şaşırtıcı değildir. Öyleki Batılılaşma hareketleri özellikle Tanzimat Dönemi (1839-1876)'nde daha da bir hız kazanarak

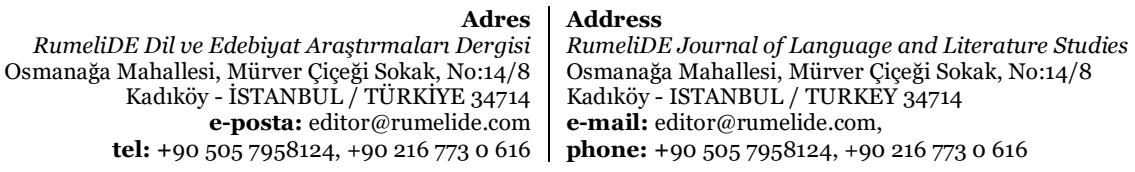


sadece askeri alanda değil ticaret ve eğitim alalarında da Fransız kurumları birebir örnek alınmıştır. Yılancığlu (2014: 51)'nun da belirttiği gibi Tanzimat Fermanı (3 Kasım 1839) Osmanlı İmparatorluğu'nun Batı ile olan ilişkisinde resmi bir dönüm noktası olmuştur. Öyle ki Batıyla, özellikle de Fransa ile çok yakın ilişkilerde bulunulur ve bu derin değişim sürecinde medeniyetin beşiği olarak kabul gören Fransa İmparatorluk için adeta bir rol model haline gelir. Diğer yandan Güzel (2015: 320) ise Fransa'nın başta eğitim ve askeri alanlar olmak üzere pek çok alanda örnek alınan bir ülke olması neticesinde İmparatorluk dönemi eğitim kurumlarında yabancı dil olarak Fransızcanın büyük talep gördüğünü dile getirmektedir.

Cumhuriyet (1923)'in kuruluşunu takiben sosyal, siyasi ve ekonomik alanlarda olduğu gibi eğitim, kültür ve dil alanında da köklü değişikliklere gidilmiştir. Kendisi de bir frankofon olan Mustafa Kemal Atatürk (Avcı, 2020)'ün çağdaş uygarlık seviyesine ulaşma yolunda yabancı dile, özellikle de Fransızcaya büyük önem atfettiği görülür (Sezgintürk, 2020: 457). Böylelikle Fransızca Türkiye Cumhuriyeti'nin ilk yıllarında da birinci yabancı dil olma özelliğini sürdürür. Ancak I. Dünya Savaşı (1914-1918)'ndan sonra dünyadaki güç dengelerinin yer değiştirmeye başlaması ile birlikte Amerika Birleşik Devletleri (ABD) siyasi, askeri ve ekonomik alanlarda dünyanın en güçlü devletlerinden biri haline gelir. II. Dünya Savaşı (1939-1945)'ndan sonra ise özellikle bilim ve teknoloji alanında dünya genelinde egemenliğini artırmasıyla birlikte İngilizce de bir dünya dili olma yoluna girer. Bu yıllarda Türk-Fransız ilişkilerinde yaşanan kimi değişiklikler neticesinde Fransızca da önemini yavaş yavaş yitirmeye başlar ve tüm dünyada olduğu gibi Türkiye’de birçok alanda yerini İngilizceye bırakır.

\section{İnternet sözlükleri}

20. yüzyılın ikinci yarısından itibaren bilim ve teknoloji alanında yaşanan gelişmelere koşut olarak basın, sinema, radyo ve televizyon gibi iletişim araçları günlük hayatın vazgeçilmez birer parçası olarak toplumsal yaşamda yer bulurlar. Ancak 1990'lı ylllarla, özellikle kişisel bilgisayarlar (PC)'ın çoğalmasıyla birlikte İnternetin de dünya genelinde yaygınlaşarak kök saldığı görülür. Bu sayede 200o'li yılların başından itibaren cep telefonu ve taşınabilir bilgisayarların kullanımı da hızla yayılır. Böylelikle bilişimiletişim teknolojileri toplumsal yaşamın hemen her alanında kendini gösterir ve gündelik yaşam alışkanlıklarında köklü değişikliklere neden olurlar (Yazıcı, 2016: 122). Wilson ve Peterson (2002: 449)'nın da belirttiği gibi özellikle küresel bilgisayar ağlarının gelişimiyle birlikte, bireylerin toplum içerisindeki diğer topluluk, grup ya da kültürlerle eşzamanlı çevrimiçi etkileşimlerinde önemli oranda artış yaşandığı gözlenmiştir. Bu yönüyle kullanımı yaygınlaşan İnternetin sosyal ve toplumsal yaşamı da yeniden yapılandırdığı söylenebilir.

Diğer yandan, söz konusu teknolojilerin yaygınlaşmasıyla birlikte Dilmen (2007: 114)'in de belirttiği gibi "bilgisayar aracılı yeni iletişim ortamları" anlamında "yeni medya" kavramı gündeme gelir. Çeçen (2019: 55)'e göre dijitalleşme ile geliştirilen bu yeni teknolojiler beraberinde, hâlihazırdaki yeni medya ortamının klasik medyadan farklarını ortaya koyan gelişmeleri de hazırlamıştır. Böylelikle Çomu (2012: 42-43)'nun da işaret ettiği gibi Web 2.0 araçları adı altındaki bu yeni ortamlara kullanıcıların katılımıyla etkileşimin gittikçe arttığı, yine kullanıcıların buralarda içerik üretebildiği ve ürettiği içeriği başkaları ile kolayca paylaşabildiği yeni bir dönem başlamıştır. Binark ve Löker (2011: 11) ise yeni medyanın bu özelliğinin bireylerin ifade özgürlüğünü artırması, bilgi ve becerilerini zenginleştimesinin dışında kendilerine kamusal alanda siyaset üretebilme imakanı verdiğinin de altını çizmektedir. Bu bağlamda "yeni medya" kullanıcılarına kendi ilgi alanları ve beğenileri doğrultusunda üretim yapabilmeleri için çok fazla seçenek ve imkân sunarak onların etkin olmalarına katkı sağlamaktadır.

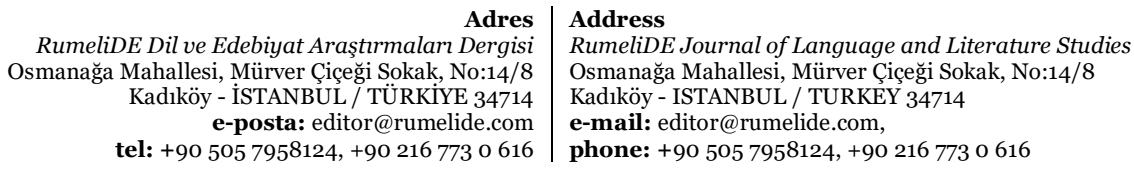


Yeni medya bağlamında İnternetin ilk dönemlerinde kullanıcılara kısıtlı bir katılım sağlayan Web 1.o'ın olanakları ölçütünde ortaya çlkan, bugün sanal sözlük, çevrimiçi sözlük ve etkileşimli sözlük olarak da adlandırılan etkileşimli ortamlardan biri de İnternet sözlükleridir (Söğüt, 2020: 48). Sonraki yllarda geniş bir kullanıcı kitlesine ulaşarak popüler birer sosyal ağ haline dönuşen bu ortamlar Sağır (2012: 26)'a göre; küreselleşmenin ve yeni medyanın hayatımıza daha çok girmesi ile eski sözlüklerin modern kavram ve durumları açıklamakta yetersiz kalmaları neticesinde alternatif sözlük arayışı ihtiyacıyla ortaya çıkmışlardır. Özellikle Web 2.o teknolojileriyle birlikte bu sözlükler daha fazla gelişme göstererek Yıldırım ve Başer (2016: 185)'in de ifade ettiği gibi İnternet girişimciliği kapsamında bilgiyi farklı şekillerde aktaran bir oluşuma dönüştürmüşlerdir.

Uçkan (2012: 23) bu sözlükleri; "gerçek zamanlı akışa dayalı çevrimiçi forumlar, topluluk yaratmaya odaklı sosyal ağlar, "urban dictionary" tarzı sözlük formatını kullanan kullanıcı içeriği siteleri ve ortaklaşa üretimin teknik altyapısını oluşturarak Wikipedia gibi örnekleri yaratan wiki'lerin bir karışımı olarak" tanımlarken Bozkurt ve Biroğul (2012: 17), "her türlü kelime, olay, durum ve kavram hakkında, kayıtlı yazarların yorumlarını içeren ve subjektif sunumlarıyla genişletilen katılımcı sözlük tarzında ă sayfası"olarak nitelemektedir. Diğer yandan Gürel ve Yakın (2007: 203) göre; "İnternet üzerinde faaliyet gösteren ve kelime ya da deyimleri alfabetik bir açılımla sunan” bu platformlar, Sağır (2012: 27) tarafından ise "kelimeleri ve olguları yeniden tanımlamak, gündelik olay ve haberleri anlık yorumlarla değerlendirmek için herkesin yazar olabildiği, deneyimlerinden hareketle tanımladığı alanlar" şeklinde değerlendirilmektedir. Tanımlardan da anlaşlabileceği gibi İnternet sözlükleri durağan bir yapıda ve belirli kavramlar hakkındaki içeriklerin yer aldığı ortamlar değil, güncel konuların ele alındığı gündemli mecralardır (Söğüt, 2020: 48). Bütün bunlarla birlikte, etkileşimli sözlükler bilgiyi oluşturma, paylaşma ve kategorilendirme özellikleğine de sahiptir. Bu bağlamda, katılımcı sözlüklerde paylaşllan bilgiler doğru ya da yanlış olarak değil sözlük yazarlarının herhangi bir konu hakkında yapmış oldukları öneri ya da görüş bildirme şeklinde değerlendirilmelidir. Sözlüklerin sıklıkla kullanılma nedenlerinden biri de bireylerin merak, bilme ve öğrenme istekleridir. Bu sebeple kuruldukları günden itibaren her yaştan bireyin sıklıkla başvurduğu birer kaynak haline dönüşmüşlerdir.

Türkiye'de bilinen önemli katılımcı sözlüklerden biri olan İnci Sözlük 16 Aralık 2009 yılında Serkan İnci önderliğinde Altımı şer, incisi ker sloganıyla plansız kurulan bir mecradır. Sansürcü zihniyetten bunaldığını dile getiren birkaç kişinin kendilerini daha rahat ifade edeceklerine inandıkları bir platform arayışı neticesinde gerçekleşir. Kullanıcılar sözlüğe ücretsiz kaydolup konular (kavramlar) hakkında yorumlar yapabilmektedir. İnci Sözlüğün en eski yöneticisi Gürkan Dündar kurulma amaçlarının, insanların herhangi bir konu hakkında duygu ve düşüncelerini özgürce dile getirebilmeleri ve aynı anda birçok bilgiye ulaşabilmelerinin olanaklı olduğunu göstermek olduğunu vurgulamaktadır. Bu bağlamda sözlüğün ansiklopedik, doğru ve tarafsız bilgilerden oluşmadığının da altını çizmektedir (Özer, 2012: 37). İnci Sözlük, Türkiye'deki Uludă̆ Sözlük, Ekşi Sözlük ya da İnstela gibi emsalleriyle kıyaslandığında; “dili erkeksidir ve pornografiye varan argo bir dil kullanılır. Sitenin yalnızca 3 (üę) temel kuralı vardır: Dini ve siyasi tartışmalara girilmemesi ve de üçüncü kişilere hakaret edilmemesidir. Kurallarının Türkiye'deki birçok İnternet sitesine göre çok daha az kısıtlayıcı olmasından ötürü 4chan'e benzetilmektedir." (İnci Sözlük, Vikipedi, 2021).

Nitekim her ne kadar İnci Sözlük'te 3. şahıslara hakaret etmek kurallara aykırı olsa da sözlük kullanıcılarının bu kurallara uymadıkları ve bu nedenle sözlüğün kimi zaman Türk mahkemeleri tarafından erişiminin engellendiği görülmektedir. İnci Sözlük kavram olarak sadece yazarların yorumlarından oluşmamakla birlikte, capsler ve swfler (small web format) aracılığıyla da kullanıcılar görüş ve düşüncelerini dile getirmektedirler. Öte yandan, İnci Sözlük’te hiçbir noktalama ya da imla

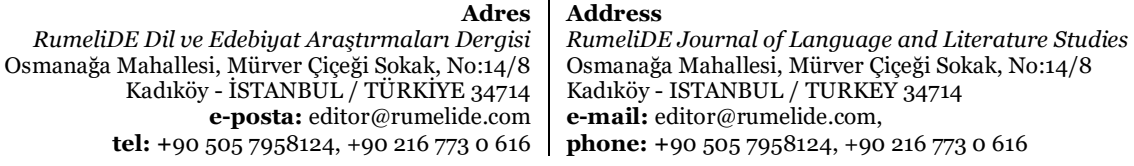


kuralına uyma zorunluluğu da bulunmamaktadır. 18 yaşından küçükler için uygunsuz içerikler sözlükte yer almamakla birlikte, sözlük kurucuları herhangi bir kanuni yaptırımla karşılaşmamak için sözlük formatına aykırı olan içerikleri de anında kaldırılmaktadır.

Türkiye'deki İnternet sözlüklerinin, özellikle katılımcı sözlük türünde dünyadaki ilk örneklerinden biri olan Ekşi Sözlük'ün hâlihazırda 1 kitap, 14 tez, 29 bildiri ve 30 makalede araştırma konusu edildiği görülmektedir (https://akademik.yok.gov.tr/AkademikArama/). Ancak doğrudan İnci Sözlük üzerine yapılmış çok az sayıda araştırmaya rastlanmaktadır. Bunlar; Dondurucu (2018)'nun Gümüşhane Üniversitesi İletişim Fakültesi Elektronik Dergisinnde yaymmlanan "Yeni medyada cinsel kimlik temelli nefret söylemi: İnci Sözlük örneği” başlıklı makalesi, yine Dondurucu (2017) 3. Uluslararası Sosyal Bilimler ve Eğitim Araştırmaları Konferansı (İtalya-Roma)'nda sunduğu “İnci Sözlük'te kadına yönelik hakaret içeren girdilerin çözümlenmesi” başlıklı bildirisi ve Türk ve Tugen (2016)'in 19. "Türkiyede Internet" Konferansı (İzmir)'nda sundukları "Dijital cemaatler ve postmodern kabile örneği: İnci Sözlük" başlıklı birdirilerdir.

\section{Çalışmanın amacı ve önemi}

Osmanlı İmparatorluğu'nun birçok alanda köklü ilişkiler kurduğu Batılı ülkerin başında Fransa gelir. Resmi olarak Kanuni Sultan Süleyman (1494-1566) zamanında başlayan siyasi, ticari (1536Kapitülasyonlar) ve diplomatik ilişkiler arada kimi kesinti, iniş ve çıkışlara rağmen asırlar boyu sürerek bir gelenek haline dönüşecektir. Tanzimat öncesinden başlayarak İmparatorluğun son yüzyllında ve Cumhuriyetin ilk yıllarının lingua franca (anlaşma dili)'sı olan Fransızca, adeta bir devlet politikası olarak hem Batı (Avrupa)'yı tanııı onlarla ilişkileri geliştirmenin hem de eğitimden sanata çağdaşlaşmanın en önemli araçlarından biri olarak kabul görmüştür (Kartal, 2017: 368). Böylelikle Türklerin Fransızlarla, dolayısıyla Fransızcayla asırlar boyu süre gelen siyasi, ekonomik, sosyal ve kültürel etkileşimleri neticesinde millet olarak bu dile özgü doğru ya da yanlış bir takım bilgi, görüş, düşünce ve algıları oluşmuştur.

Bu çalışmada, Türkiye'de en çok kullanılan sosyal medya platformlarından biri olarak bilinen İnci Sözlük'te üretilen “Fransızca” algısının incelenmesi amaçlanmaktadır. Bunun için sözlükteki Fransızca başlıklı girdilerin derlenip Web tabanlı söylem çözümlemesi yoluyla incelenerek sözlük yazarlarının bu dile ilişkin görüş, düşünce ve algıları ortaya konmaya çalışılacaktır. Böylelikle İnci Sözlük yazarları örneği aracıllğıyla elde edilebilecek bu türden bulgular sayesinde Fransızcanın Türk toplumu nezdindeki "algısı" hakkında da fikir sahibi olma imkânı doğacaktır. Bu da özellikle Fransızcaya değin toplumdaki olumsuz algıların giderilmesi ve dünyada yaygın olarak kullanılan bir dil/ yabancı dil olma özelliğiyle eğitim sistemimizde de hak ettiği yeri bulması yönündeki gayret ve çalışmalara katkı sağlayacaktır. Öte yandan, yeni bilgi ve enformasyon teknolojilerinin gelişimiyle birlikte Web tabanlı söylem çözümlemesi üzerine yapılan çalışmalar son yıllarda artış gösterse de henüz istenilen düzeyde olmadığı görülmektedir. Bu bağlamda mevcut çalışma alandaki araştırmacılar için sınırlı da olsa bir kaynak teşkil edebilir.

\section{Yöntem}

\section{Araştırma deseni}

İnci Sözlük yazarların Fransızcaya dair duygu, düşünce ve algılarına, platformadaki yazılı yorumlarının, bir başka ifadeyle söylemlerinin çözümlenmesi yoluyla ulaşılması amaçlandığından çalışma nitel araştırma yöntemlerinden fenomenolojlik (olgubilim) araştırma desenine göre yapılandırılmıştır.

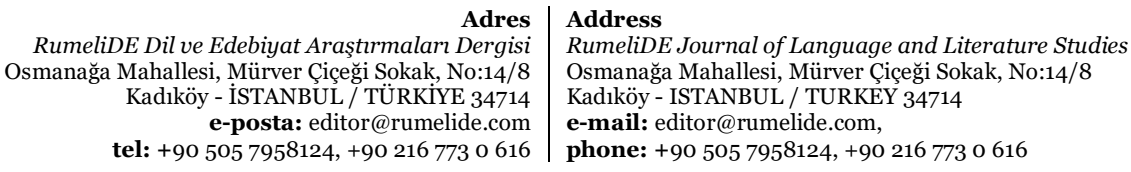


Merriam (2018: 25)'e göre fenomenolojik desenli araştırmalarda öncelikle katılımcllardan elde edilen bilgilerin çeşitliliğinin artırılması ve derinliklerinin sağlanması amaçlanır. Bu sebeple, araştırma "olgusu" (fenomen) da önyargılardan bağımsız ve gerçekte var olduğu gibi ele alınıp değerlendirilmelidir.

\section{Verilerin derlenmesi ve bütüncenin oluşturulması}

Araştırmanın yapıldığı tarih itibariyle İnci Sözlük (http://www.incisozluk.com.tr/) platformu üzerinde "Fransızca" anahtar kelimesiyle yapılan bir arama neticesinde yaklaşık 11 yllık bir zaman dilimi (Aralık 2009- 2021 Nisan) içerisinde bu başlık altında değişik tarihlerde (ilki 25.12.2009, sonuncusu ise 27.08.2020'de tarihinde girilmiş) girilmiş 95 girdi (entry)'ye ulaşılmıştır. Girdiler (yorumlar), giriş tarihleri göz önünde bulundurlarak en eskiden en yeni olana doğru sıralandırılarak "İ" (İnci) harfi kısaltmasıyla $\dot{I} 1$ 'den İ95'e kadar numaralandırılarak çalışmanın bütüncesi oluşturulmuştur. Bu türden sayısal (dijital) platformalardaki verilerin/girdilerin kimi zaman silinebilir olması durumu da göz önünde bulundurularak derlenen girdilerin tamamı ayrı bir Word dosyasına aktarılarak kayıt altına alınmıştır. Diğer yandan, kimi yorumlar beraberinde resim, karikatür ya da başka ortamlara yönlendiren bağlantı (link)'lar içerdikleri için aynı şekilde onlar da Word ortamına aktarılarak içeriklerin korunması sağlanmıştır.

\section{Verilerin çözümlenmesi}

Etkileşimli olarak adlandırılan sayısal (dijital) ortamlarda katılımcılar genel olarak klavye üzerinden yazarak ve bilgisayar ekranından yazılanları/ metinleri okuyarak bir anlamda klasik sözlü iletişim modeli çerçevesinde iletişim kurarlar. Böylelikle çevrimiçi etkileşim bir tür "söylem", yani gerçek anlamda dilin icraatı yoluyla gerçekleşmiş olur. Bu sebeple Baron (1984: 124)'un da vurguladığı gibi bilgisayar tabanlı iletişim kullanımları, genel olarak bilgisayarlar hakkında yapılan tartışmaların bir parçası olarak değil, daha çok insan dili üzerine yapılan çalışmaların bir parçası olarak değerlendirilmelidir.

$\mathrm{Bu}$ yaklaşım çerçevesinde çalışmanın derlemini oluşturan sözlükteki girdilerinin (görüşlerin) her biri kendi başına bir "söylem" olarak ele alınarak "Web tabanlı söylem çözümlemesi" (Herring, 2004) yaklaşımıyla çözümlenecektir. Herring (2004: 4)'in de işaret ettiği gibi Web tabanlı söylem çözümlemesi bir teori ya da bir yöntemden daha ziyade bir yaklaşım olarak kabul edilmektedir. Ayrıca bu yaklaşımın altında yatan teorik varsayımlar, geniş çapta klasik söylem analizinin teorik varsayımlarının aynısıdır. Diğer yandan, temel yöntembilimsel yaklaşımı dil odaklı içerik analizidir. Bu analiz türü, seçilmiş bir metin örnekleminde kimi dilsel olguların gözlemlenmesi yoluyla doğrudan nitel amaçlı kullanılabileceği gibi bu olguların kodlanması, sayılması ve bunların göreceli frekanslarının elde edilmesi için nicel amaçlı da kullanılabilir.

Böylelikle van Dijk (1997: 2)'in de vurguladığı gibi, bu türden platformlardaki içeriklerin (girdiler) de etkileşimli çevrimiçi ortamlar için öngörülen söylem çözümlemesi teknikleri aracılığıyla çözümlemesi mükündür (Akt. Mazur, 2004: 1074). Ancak Cumming ve Ono (1997)'ya göre ise bu söylemler çeşitli düzeylerde çözümlenebilseler de pek çok çalışmada artık katı dilsel söylem (örneğin, kelime ve cümlelerin sıraları gibi) olgusuna odaklanmak yerine, içerikteki bilgilerin söylemin diğer düzeyleri ve boyutları ile olan uyumu incelenmektedir (Akt. Marra, Moore ve Klimczak, 2004: 24-25). Benzer şekilde De Wever, Schellens, Valcke ve Van Keer (2006: 7)'in de söylediği gibi Web tabanlı içerik çözümlemelerinde genellikle yazı (transkript) düzeyinde yer almayan bilgilerin ortaya çıkarılması amaçlandığından çevrimiçi tartışmalar hakkında da ikna edici kanıtların elde edilebilmesi için içeriğin

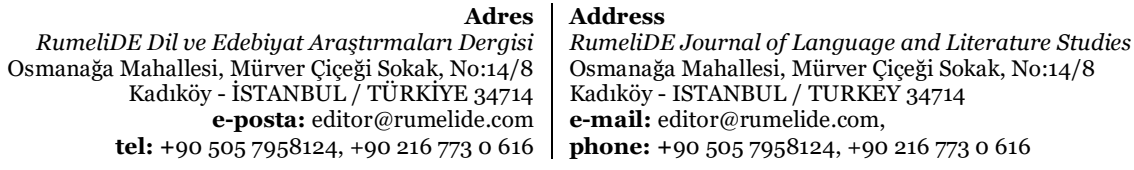


derinlemesine anlaşılması gerekmektedir. Bu sebeple yorumlar, okuyucularına (alıcılar) gerçekte katılımcıların (vericiler) neler düşünüp, neler hissettiklerini tam olarak yansıtamayacağı için araştırmacının çözümleme sırasında söylemde doğru olduğuna inandığı yorumlar için mümkün olan en güçlü kanıtları oluşturması gerekir.

Bu düşünceden harketle çalışmada sadece sözlüğün arayüzündeki içerikler (girdiler) değil içeriklerdeki kimi bağlantılar (linkler) yoluyla ulaşılabilen sayfalardaki yorumlar da söylem çözümlemesine dâhil edilmiştir. Diğer yandan çalışmanın amacıyla doğrudan bağlantısı olmadığı düşünülen girdiler ise "Diğer" kategorisi adı altında sınıflandırılarak çözümlemeye dâhil edilmemiştir. İlk aşamada, İnci Sözlük yazarlarının "Fransızca" ile ilgili bilgi, görüş ve düşünceleri (algıları), sözlükteki "söylemlerinin" (girdilerinin) çözümlemesi yoluyla sayısallaştırılmıştır. Ardından söz konusu bilgi, görüş ve algıların tamamını kapsayacak şekilde ana temalar (kategoriler) belirlenmiştir. Söylemler türlerine göre bu temalar altında çoktan aza doğru giden sıklıklarına göre sınıflandırılarak tablolaştırılmıştır. Bu arada, genelde yazarlara ait her bir girdide, diğer bir ifadeyle "yorumda"/"söylemde" sadece yukarıda sözü edilen ana kategoriler bağlamında tek bir düşünce, görüş ya da algı dile getirilirken, kimi zaman da yine tek bir girdide birden fazla temaya dair görüş, düşünce ve algı dile getirildiği görülmüştür. Bu türden girdilerin verileri tablolarda "frekans" sütunlarına eklendiği gibi, kodlamaları da "girdi kodları" sütünunda içerdikleri "söylem” (entry) oranında yinelenmiştir.

Son olarak, olgubilimsel (fenomenolojik) desenli araştırmalarda üretilen bilgilerin geçerliliğinin sağlanması için kullanılan yöntemlerinden biri olan "öznelerarası geçerlilik” (Hall ve Lindzey, 1985, akt. Özdemir, 2010: 335) yaklaşımıyla girdilerin çözümlenmesi yoluyla elde edilen veriler (algılar) iki uzman araştırmacı tarafından bağımsız olarak değerlendirilerek karşılaştırılmıştır. Karşılaştırma neticesinde her iki uzman arasında uyum yüzdesini belirlemek için ise Miles ve Huberman (1994: 64) tarafindan önerilen Güvenirlik = görüş birliği/ görüş birliği + görüş ayrlhğı $\times 100$ formülü kullanılmıştır. Söz konusu formüle göre çalışmadaki uzmanlar arası uyum yüzdesi ise \%92 olarak hesaplanmıştır.

\section{Bulgular}

Söylem çözümlemesi neticesinde bütüncedeki girdilerin tamamı ( $\mathrm{f}=95)$ sırasıyla; yansız (nötr), olumsuz, olumlu, olumsuz ve olumlu (bir arada), ironik, cinselliği çağrıştıran dil ve diğer teması olmak üzere toplam 7 (yedi) ana tema (başlık) etrafında kategorilendirilmiştir (Tablo 1).

Tablo 1. İnci Sözlük’teki Fransızca başlıklı girdilerin ana temalara göre dağılımı

\begin{tabular}{lll}
\hline Söylemlere dair ana temalar & f & $\mathbf{\%}$ \\
\hline Yansız söylemler & 30 & 31,5 \\
Olumsuz söylemler & 23 & 24,2 \\
Olumlu yorumlar & 20 & 21 \\
Olumsuz vs olumlu söylemler & 5 & 5,2 \\
Ironik söylemler & 2 & 2,1 \\
Cinselliği çağrıştıran bir dil olduğuna dair söylemler & 2 & 2,1 \\
Diğer söylemler & 13 & 13,6 \\
\hline Toplam & $\mathbf{9 5}$ & $\mathbf{1 0 0}$ \\
\hline
\end{tabular}

Tablo 1'de görüldüğü üzere girdilerin ağırlıklı olarak sırasıyla yaklaşık 1/3 (\%31,5)'nü yansız, 1/4 (\%24,2)'nü olumsuz ve 1/5 (\%21)'i ise olumlu söylemlerden oluşmaktadır. Saylları az olmakla birlikte

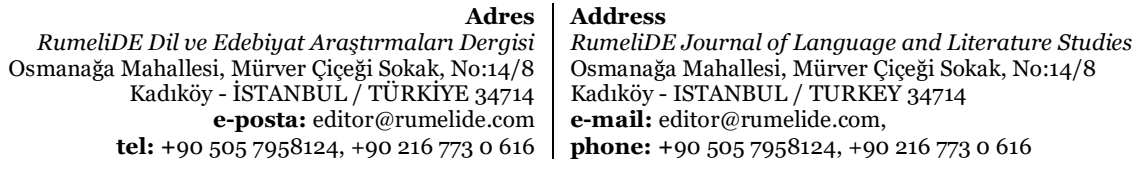


$(\mathrm{f}=5$ ) olumsuz başlayıp olumluya evrilen (olumsuz versus $($ VS) olumlu), ironik $(\mathrm{f}=2)$ ve yine aynı sayıda $(\mathrm{f}=2)$ cinselliği çağrıştıran bir dil olmasına yönünde yorumların varlığı da dikkat çekmektedir. Diğer yandan, girdilerin \%13,6 ( $\mathrm{f}=13$ )'sının ise herhangi bir şekilde araştırmanın amacıyla bağdaşmadığ gözlemlenmiştir. Böylelikle söz konusu girdiler (söylemler) diğer teması adı altına kodlanarak çözümlemeye dâhil edilmemiştir.

1. Yansız Söylemler: Bu tema altında Türk Dil Kurumu Sözlüğü (TDK, 2021)'nün“olumlu ya da olumsuz yargı içermeyen, tarafsız” tanımı esas alınarak çözümlenen girdiler (söylemler) sınıflandırılmıştır. Derlemdeki girdilerin hemen hemen $1 / 3$ 'ünün $(\mathrm{f}=30)$ bu yöndeki söylemlemlerden oluştuğu görülmektedir. Çözümleme neticesinde girdilerden bu tema bağlamında elde edilen söylemler, alt tema ve sıklıklarına göre aşağıdaki gibi kodlanmıştır (Tablo 2).

Tablo 2. Yansız söyleme dair alt temaların dağılımı

\begin{tabular}{|c|c|c|}
\hline Yansız söyleme dair alt temalar & Girdi kodları & $\mathbf{f}$ \\
\hline Fransızca bildiğini gösterme & $\begin{array}{l}\dot{\mathrm{I}} 5, \text { İ9, İ13, İ26, İ28, İ31, İ33, İ35, İ63, İ69, İ70, } \\
\text { İ80, İ81, İ93 }\end{array}$ & 14 \\
\hline Fransızcanın öğrenilmeye çalışılan bir dil olması & İ23, İ30, İ53, İ72 & 4 \\
\hline Fransızca öğrenmek ve geliştirmek için tavsiye isteme & $\dot{\mathrm{I}}_{44}, \dot{\mathrm{I}}_{52}, \dot{\mathrm{I}}_{94}$ & 3 \\
\hline Fransızca öğretme konusunda destek olmak istenmesi & İ $32, \dot{\mathrm{I}} 40, \dot{\mathrm{I}} 58$ & 3 \\
\hline $\begin{array}{l}\text { Fransızca öğrenmek ve geliştirmek için önerilerde } \\
\text { bulunma }\end{array}$ & İ59, $\mathrm{I} 65$ & 2 \\
\hline $\begin{array}{l}\text { Fransızca ile ilgili tanım yapılmaması gerektiğini } \\
\text { vurgulama }\end{array}$ & $\dot{\mathrm{I}}_{41}$ & 1 \\
\hline Fransızca eğitim alındığı konusunda bilgi verme & $\dot{\mathrm{I}}_{51}$ & 1 \\
\hline $\begin{array}{l}\text { Fransızcanın değişik dillerle olan benzerlik ve } \\
\text { farklıklarını belirtme }\end{array}$ & $\dot{I}_{71}$ & 1 \\
\hline $\begin{array}{l}\text { Fransızcanın öğrenilmesi gereken dil olmasını } \\
\text { vurgulama }\end{array}$ & $\dot{\mathrm{I}}_{78}$ & 1 \\
\hline
\end{tabular}

Tablo 2'de görüldüğü gibi derlemdeki girdilerin 1/3'ünü oluşturan ve en sıkllkla yinelenen ( $\mathrm{f}=30$ ) yansız söylemler 9 (dokuz) alt tema çerçevesinde sınıflandırılmıştır. Söz konusu girdilerin neredeyse yarısının ( $\mathrm{f}=14$ ) Fransızca yazılmış girdiler olduğu dikkat çekmektedir. Böylelikle yazarların Fransızcayı ne denli iyi bildiklerini kanıtlamak istedikleri söylenebilir. Diğer yandan, sadece Fransızca yazılan bu iletilerde kimi sözlük yazarlarının argo bir dille görüş ve düşüncelerini dile getirdiğikleri ya da Fransız diline yönelik herhangi bir düşünce (yargı) ifade etmeyen sadece küfür içeren girdiler bıraktıkları görülmektedir. Örneğin İ13 kodlu girdiye bakıldığında, yazarının bir yandan Fransızcayı ne denli iyi bildiğini diğer sözlük yazarları ve okuyucularına kanıtlamak istediği, diğer yandan da Fransızcaya dair herhangi bir duygu, düşünce ve yargı içermeyen ancak salt küfür içeren bir ileti girdiği belirlenmiştir: "ta mere suce des ours dans la foret" [dal ama, 11.09.2010]. İ28 kodlu girdide de benzer şekilde yazarın Fransızcaya dair herhangi bir duygu, düşünce ya da yargı içermeyen fakat sadece bu dili ne denli iyi bildiğini gösteren küfür içerikli yorum yapmıştır: "je vais mettre le yaourt a la chatte de ta mere et je vais la baiser jusqu'il devient ayran" [triple o, 07.08.2011]. Son olarak, İ93 kodlu "bonjour mesdames!

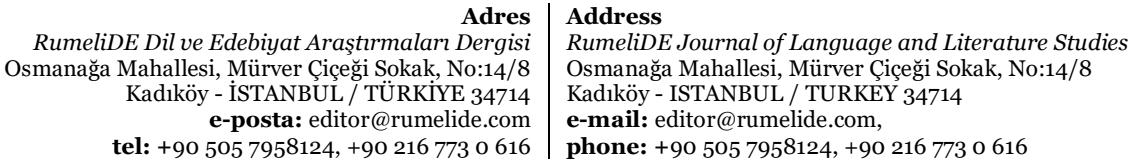


parle francais avec moi sup!” (Merhaba bayanlar! Benimle Fransızca konuş lütfen!)3 [elkahhar, 22.06.2018] iletinin sahibi de Fransızca bildiğini göstermeye çalıştığı söylenebilir.

Söylemlerin geri kalan diğer yarısındaysa sırasıyla Fransızcanın öğrenilmeye çalışılan bir dil olmasına dair girdiler ( $\mathrm{f}=4$ ) göze çarpmaktadır. Örneğin; İ3o kodlu "bu sene başhcaz öğrenmeye bakalım nasıl olcak binler" [xacapzter, 22.09.2011] girdide sözlük yazarı Fransızca öğrenme hazırlı̆̆ında olduğunu belirtirken, İ72 kodlu girdide ise yazarın Fransızca öğrenmek için kaynak arayışında olduğunu diğer sözlük yazarlarına ve okuyucularına bildirdiği anlaşılmaktadır: "bana kaynak gönderin panpalarım. artık öğrenmenin zamanı geldi” [anarsist panpa, 23.05.2014].

Bir diğer alt tema kapsamında sözlük yazarlarının diğer yazar ve okuyuculardan Fransızca öğrenebilecekleri yerleri ya da öğrenme tekniklerini kendileri ile paylaşılmasını istedikleri $(\mathrm{f}=3)$ görülmektedir. Örneğin İ52 kodlu "birkaç aya başlama ihtimalim var binler istanbulda var mı kurs önerileri bir de 7-8 aya bişeyler kapılır mı panpalar çok zor mudur" [yarma seftali, 16.01.2013] girișten anlaşıldığı üzere yazar Fransızca öğrenmeyi planladığını, diğer sözlük yazarlarından İstanbul'da Fransızca eğitim alabileceği kurs önerisinde bulunmalarını istemektedir. Yazar ayrıca belli bir zaman aralığında bu dili öğrenmenin mümkün olup olmadığını ve dilin zorluğunu sormaktadır. Benzer şekilde bir başka girdi (İ94) de yazar Fransızca öğrenmeye başladığını ve bu dili kendi çabasıyla öğrenen olup olmadığını sormaktadır: "kendi kendine öğrenen var mı sipariş ettiğim kitap bugün geldi, çalışmaya başlyorum" [sang noir, 13.02.2020].

Diğer yandan yansız söylemlere bakıldığında aralarında bir önceki alt temayla aynı sayıda $(\mathrm{f}=3)$ Fransızca bilen sözlük yazarlarının bu dili öğrenmek ya da geliştirmek isteyen diğer yazarlara ve okuyuculara yardım edebileceklerini belirten girdiler de bulunmaktadır: "biliyorum lan ben bunu, çeviri falan isteyen varsa rahatsız etsin" [i்32-journalci, 25.09.20119] ve "kafanıza takılan bir şey olursa pmden bana ulaşın" [İ58-ccc rammstein ccc, 16.05.2013]. Benzer şekilde kimi sözlük yazarları da Fransızcasını geliştirmek isteyenler ya da yeni öğrenmeye başlayanlar için önerilerde bulunmaktadırlar (f=2). Örneğin; "bilindiği sürece dert yoktur, aller, avoir ve etre bu üçü bilinecek lan! passe compose ve imparfait'yide sökerseniz oo deme keyfinize, le/la ayrmı ise ayr gibiyor adamı ama kitap okudukça alş̧llyyor. vouloir pouvoir'da bilinecek skerler. c.o.d c.o.i ise işleri kolaylaşttrtyor, takılın bunlarada" [İ59-isemelisicmaliayin, 16.05.2013].

Son olarak bu kategoride sirasıyla yazarların birer sıklkla ( $\mathrm{f}=1$ ); Fransızcayla ilgili tanım yapılmamasına: "tanim yapmasaniza huur cocuklari" [İ41-durrizade abdullah efendi, 23.01.2012], geçmişte nasıl Fransızca eğitim aldığına: "teyy zamanında lisede eğitimini aldıydım. her ders amk hocası bana okuttururdu fransızca metinleri. telaffuz miras işte” [i்51-caesar did nothing wrong, 28.12.2012], Fransızcanın diğer dillerle karşılaştırılmasına: "ingilizceden bi farkı yok amk" [İ71-joseph piedra, 22.02.2014] ve en sonunda Fransızcanın öğrenilmesi gereken bir dil olduğuna ve diğer yazarların basit de olsa Fransızca öğrenebilmeleri için bir videoya yönlendirilmesine dair söylemler içeren girdilerin yer aldığı görülmektedir: "http://www.youtube.com/watch?v=xsssB4ikOGs öğrenin beyler" [i்78-kerhanecibasi, 08.08.2014].

2. Olumsuz Söylemler: Olumsuz söylem teması da TDK Sözlüğü (2021)'ndeki "yapıcı ve yararlı olmayan, hiçbir sonuca ulaşmayan, gözetilen amaca veya beklenilene uygun olmayan, menfi, negatif"

3 Kimi Fransızca girdiler (yanlış bile olsalar) orijinal hallerine sadık kalınarak tarafımızdan Türkçeye çevrilmiştir.

Adres Address

RumeliDE Dil ve Edebiyat Araştırmaları Dergisi $\quad$ RumeliDE Journal of Language and Literature Studies

Osmanağa Mahallesi, Mürver Çiçeği Sokak, No:14/8 Osmanağa Mahallesi, Mürver Çiçeği Sokak, No:14/8

Kadıköy - İSTANBUL / TÜRKIYE 34714 Kadıköy - ISTANBUL / TURKEY 34714

e-posta: editor@rumelide.com $\quad$ e-mail: editor@rumelide.com,

tel: +90 $5057958124,+90216773$ o 616 phone: +90 505 7958124, +90 216773 o 616 
tanımı esas alınarak oluşturulmuştur. Aşağıda Tablo 3’te sözlük yazarlarının Fransızca hakkındaki olumsuz bilgi, düşünce ve yargıları, alt başlık ve sıklıklarına göre sınıflandırılmıştır.

Tablo 3. Olumsuz söyleme dair alt temaların dağılımı

\begin{tabular}{|c|c|c|}
\hline Olumsuz söyleme dair alt temalar & Girdi kodları & $\mathrm{f}$ \\
\hline Öğrenilmesi zor bir dil olması & İo6, İ12, İ20, İ25, İ46, İ48, İ 57 , İ76 & 8 \\
\hline Telaffuzunun zor olması & İ19, İ22, İ25, İ66, İ88, İ89 & 6 \\
\hline Yazıldığı gibi okunmayan bir dil olması & İ10, İ54 & 2 \\
\hline Sevilmeyen bir dil olması & İ5o, İ84 & 2 \\
\hline Çabuk unutulan bir dil olması & İo6, İ39 & 2 \\
\hline Konuşmasının zor olması & İ6o & 1 \\
\hline Fiil çekimlerinin zor olması & İo4 & 1 \\
\hline Gramerin zor olması & İ56 & 1 \\
\hline Telaffuz kurallarının net olmaması & İ66 & 1 \\
\hline Aksanının zor olması & Í62 & 1 \\
\hline Kaba bir dil olması & $\dot{I}_{54}$ & 1 \\
\hline \multirow[t]{2}{*}{ Kulağa itici gelmesi } & İ9o & 1 \\
\hline & Toplam & 27 \\
\hline
\end{tabular}

* Siyah işaretlenmiş girdilerde birden fazla söyleme ulaşılmıştır.

Tablo 3’te görüldüğü üzere derlem kapsamındaki 23 girdide sözlük yazarlarının Fransızcaya değin toplam 27 olumsuz söylemine ulaşılmış ve bu söylemler 12 alt tema altında kodlanmıştır. Söz konusu söylemlerin yaklaşık 1/3’nün (f=8) Fransızcanın öğrenilmesi zor bir dil olmasına yönelik söylemlerden oluşuğu görülmektedir. Bu bağlamda, $\mathbf{I} 48$ kodlu girdinin yazarı: “öğrendim sanıyorsun, sonra bir fransızın nasıl fransızca konuştuğunu görüyorsun bir gibim bilmediğini fark ediyorsun. ingilizce gibi değil yani” [caps lock, 01.09.2012] ifadesiyle bu dili bildiğini sanan birinin dahi bir Fransızın konuştuğunu gördükten sonra aslında bu dili çok da iyi bilmediğini, İngilizce kadar kolay olmadığını dile getirmektedir. Benzer şekilde bir diğer yazar da Fransızcadan birkaç örnek cümle alıntılıyarak bu dilin öğrenilmesine dair zorluğu ifade etmektedir: "je m'apelle je ne vais pas bien je vais bien comment vous appeles-vous dıbına koyim çok zor dil lan” [ذ'57-ayvilteykyuurvirginity, 12.05.2013].

$\mathrm{Bu}$ ana tema çerçevesinde benzer bir şekilde sıklıkla dile getirilen bir başka olumsuzluk ise Fransızcanın telaffuzunun zor olması şeklindedir ( $\mathrm{f}=6)$. Örneğin; İ88 kodlu girdide yazar: "telafuzu aşırı derece taktan olan dildir" [lord yurius, 03.12.2017] şeklinde bir yorumda bulunarak Fransızcanın telaffuzunun zorluğundan yakınmaktadır. İ25 kodlu girdide ise başka bir yazar benzer bir bakış açısıyla hem bu dili öğrenmenin hem de telaffuzun zorluğunu dillendirmektedir: "öğrenmek 5 kilo taşşak ister, öğrenmesi ayrı zor, kullanması ayrı zor, diksiyonu tutturmak tamamen zor” [caps lock, 24.07.2011].

Diğer yandan sıklık bakımından bir önceki alt temalara oranla az $(\mathrm{f}=2)$ da olsa; Fransızcanın yazıldığı gibi okunmayan bir dil olması: "telaffuz konusunda uçar da uçar amk fransızlart. "noeud" diye bir şey var elemanlar bunu "nö" diye okur, amk mallart. (noeud=düğüm)" [İ89-psychofucker, 04.12.2017], sevilmeyen bir dil olması: "zamanında ruslar bunu bilince elit oluyorlarmış amk hiç sefmem" [ī்overkolik200o, 22.12.2012] ve etkin bir şekilde kullanılmadığı takdirde çabuk unutulabilen bir dil olması: “dıbına çaktığım dilini öğrenmesi zor, öğrenip konuşmayınca unutması kolay, 3 yıl önce 2

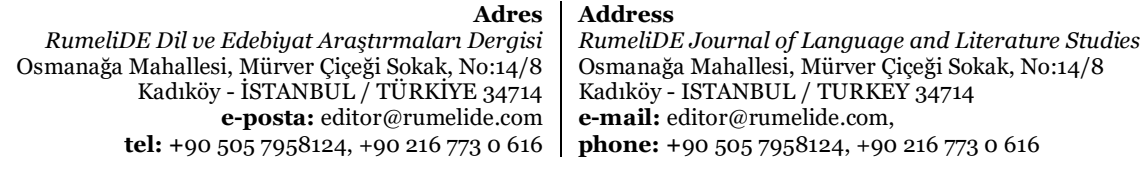


fransız cıvırla 2 kelam edelim dedik yarraa yemiş gibi kaldık, küfür edip ortamdan uzaklaştık" [İo6tas kagit yarak, 14.03.2010] türden söylemler de bulunmaktadır.

Son olarak derlemde olumsuz söylem kapsamında sözlük yazarlarının birer sıklıkla (f=1); Fransızca konuşmanin zorluğu: "merde amk merde je ne parle pas francais amk" [i்6o- cukuyle golf oynayan adam, 16.05.2013], fiil çekimlerinin karmaşıklğ̆r: "sie almancayla birmiş almancada present ta fiilin öznelere göre bir çekimi var fr de 1. grup için ayrı 2. grup için ayrı zaten 3. gruptaki fiillerin hepsi karmakarışık conjugeuer edilio ve burdan saint joseph te zamanında français hocam olmuş monsieur ange michel e de selam ederim hey gidi günler" [İo4-meow this is kittyboy, 05.03.2010], dilbilgisinin sıkıcı ve zor olması: "2 hafta önce bir hevesle öğrenmeye başlamıştım kendi kendime uff çok sıkıcı ve zor bu dibına soktuğumunun grameri" [İ56- caesar did nothing wrong, 07.04.2013], sesletim kurallarun net olmaması: "ingilizceyi bile telafüz etmeyi sevmiyorken bu dilin ben amk muallak dilidir" [İ66-ol de vuralim sabri reis, 30.07.2013], aksanının zorluğu: "bildiğim halde konuşmayı sevmediğim aksanım gibtiğimin dili" [İ62-boxerdaki piton, 17.05.2013], bilinenin aksine romantik değil kaba bir dil olmast: "beaucoup yazar taku diye okursunuz bu dili de dunyanin en kibar dili diye pazarlarlar sonra. elime anlatin siz onu edit: ciddi sanan dallama franszz hanginiz?” [i்54-jorgen knutsen, 01.02.2013] ve son olarak bu dilde konuşmaların kulak tırmaladığı ya da itici olduğu şeklinde söylemleri yer almaktadır: "kulak giben dil. bi de isidin bi infazinda elemanlar fransizca konusuyordu. bu fransa yarragi yiyecek ileride, ahahaha" [İ9o-ilk turk shichibukai, 04.12.2017].

3. Olumlu Söylemler: "Gözetilen amaca veya beklenilene uygun, yararlı, müspet, pozitif" (TDK Sözlüğü, 2021) tanımından hareketle sözlük yazarlarının Fransızcaya dair olumlu görüş, düşünce ve yargıları olumlu söylem ana teması altında alt başlık ve sıklıklarına göre aşağıda Tablo 4'deki gibi sınıflandırılmıştır.

Tablo 4. Olumlu söyleme dair alt temaların dağılımı

\begin{tabular}{|c|c|c|}
\hline Olumlu söyleme dair alt temalar & Girdi kodları & $\mathbf{f}$ \\
\hline Sevilen bir dil olması & $\dot{\mathrm{I}}_{3}, \dot{\mathrm{I}}_{42}, \dot{\mathrm{I}} 67, \dot{\mathrm{I}} 85, \dot{\mathbf{I}} 86$ & 5 \\
\hline Dinlemesi keyifli ve kulağa hoş gelmesi & İ, İ67, İ68, İ83 & 4 \\
\hline Öğrenilmek istenen dil olması & İ36, İ38, İ68, İ86 & 4 \\
\hline Müziğin dili olması & İ16, İ86, İ92 & 3 \\
\hline Çekici bir dil olması & İ17, İ91 & 2 \\
\hline Öğrenmesi keyifli dil olması & İ21, İ27 & 2 \\
\hline Romantik ve aşkın dili olması & İ27 & 1 \\
\hline Kibar dil olması & İ95 & 1 \\
\hline Karizmatik bir dil olması & İ47 & 1 \\
\hline Elit bir dil olması & İ64 & 1 \\
\hline Aksanın güzel olması & İ87 & 1 \\
\hline Toplam & & $\mathbf{2 5}$ \\
\hline
\end{tabular}

Sözlük yazarlarının derlemdeki 20 girdisinde Fransızcaya ilişkin 25 olumlu söylemine ulaşılarak bu söylemler (girdiler) 11 alt başlığa göre sınıflandırılmıştır. Fransızcanın sevilen bir dil olması alt başlı̆ındaki girdilerin bu kategorideki diğer olumlu girdilere kıyasla sayıca en fazla olması $(\mathrm{f}=5)$ dikkat çeken bir durumdur. Örneğin İo3 kodlu söylemde yazar Fransizcayı "süper bişey lan bu" [laan, 25.12.2009] diye tanımlarken, $\mathbf{I} 42$ kodlu girdinin yazarı ise Fransızca bildiğini gururla başkalarına

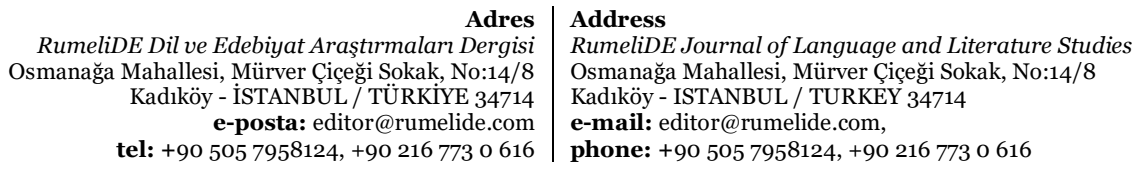


duyurmak istediğini dillendirmektedir: "fransızca bilen var mı? Sorusuna oui oui oui je parle français diye atlamak istediğim dil neden bilmem” [kskleecylko, 8.03.2012]. Hemen ardından gelen sonraki iki alt temada ise aynı sıklıkta ( $\mathrm{f}=4$ ) sırasıyla; Fransızcanın dinlemesi keyifli ve kulağa hoş gelen bir dil olmass: "acayip seviyorum bu dili konuşmalar falan çok hoşuma gidiyor" [i்6- sozlugun reyisiyim, o8.08.2013] ve sevilen dil olmasının yanı sırsa bu dili öğrenmek istediklerini ifade eden söylemler gelmektedir: “öğrenmem lazım iyice ilgimi çekmeye başladı” [İ36- wesley, 14.12.2011]

Bir başka alt temada sözlük yazarlarının Fransızcanın müziğin dili olduğuna ve bu dilde müzik dinlemenin ne denli keyif verici olduğuna dair söylemleri ( $\mathrm{f}=3$ ) yer almaktadır. İ86 kodlu girişte yazar: "sempati duyduğum, öğrenmek istediğim, kullanarak şarkılar söylemek istediğim dil. bana bu dili sevdirenler de şarkıcılar (stromae, zaz)" [black is back, 29.06.2017]'dır derken, İ92 kodlu girdide ise yazar, hiphop tarzının Fransızcaya yakıştığının altı çizmektedir: "Hiphop en güzel bunla oluyor bence. almanca da idare eder" [bennetwork, 11.06.2018].

Diğer alt temalara bakıldığında, sözlük yazarlarının benzer şekilde; Fransızcanın çekici bir dil olduğuna $(\mathrm{f}=2)$ : "sessiz konuşunca çok çekici" [i்17-sormovsky, 25.12.2010] ve öğrenilmesinin oldukça keyifli olduğuna yönelik girişleri bulunmaktadır: “ogreniyorum, inanilmaz zevkli..." [İ21-vforvagina, 23.03.2011] .

$\mathrm{Bu}$ kategoride son olarak birer sıklıkla (f=1), Fransızcanın romantik ve aşkın dili olduğu: "beyler ben lisede fransızca okudum harbi eglenceli dil eger ne biliyim biliyorsanız kızlara azıclk fransızca konusun direk tav oluyorlar adam bosuna askın dil dememı" [İ27- rouking, 02.08.2011], kibar bir dil olduğu: "çok kibar bir dil aq, bizimki gibi çok kaba değil" [İ95- buneamk123, 26.08.2020], karizmatik bir dil olduğu: "karizmatik dildir" [İ47-fuckoftheworld, 15.08.2012], bu dili bilmenin kişiyi ayrıcalıkh (elit) kıldığı: “bilmek ayrıcalktır bölümüm gereği öğreniyorum” [İ64- bladder, 20.06.2013] ve aksanı güzel bir dil olduğu: "aksanımı sevdiğim” [M17- bacak fetisi, 01.10.2017] şeklinde söylemler tespit edilmiştir.

4. Olumsuz versus olumlu söylemler: Bu tema altında sözlük yazalarının Fransızcaya yönelik aynı girdi (söylem) içerisinde hem olumlu hem de olumsuz algılarına yer verilmiştir (Tablo 5).

Tablo 5. Olumsuz versus olumlu söyleme dair alt temaların dağılımı

\begin{tabular}{llc}
\hline Olumsuz versus olumlu söyleme dair alt temalar & Girdi kodları & f \\
\hline Öğrenilmesi zor olmasına rağmen romantik dil olması & İo1 & 1 \\
Öğrenilmesi zor olmamasına rağmen fiillerin zor olması & İ34 & 1 \\
Yazıldığı gibi okunmamasına rağmen güzel bir dil olması & İ55 & 1 \\
Telaffuzun zor olmamasına rağmen bazı kuralların karmaşı olması & $\dot{\mathrm{I}} 61$ & $\mathbf{1}$ \\
Telaffuzu zor olmasa da diğer diller bilindiği takdirde kolay öğrenilmesi & İ74 & $\mathbf{1}$ \\
\hline & Toplam & $\mathbf{5}$ \\
\hline
\end{tabular}

Yukarıdaki Tablo 5’te görüldüğü gibi çalışmanın derleminde İnci Sözlük yazarlarının Fransızcaya ilişkin aynı girdi içerisinde hem olumsuz hem de (versus) olumlu söylemlerinin yer aldığ 5 (beş) farklı girdiye ulaşılmıştır. Söz konusu girdilerdeki karşıt söylemler şu şekilde sıralanabilir: Fransızcanın Almanca gibi öğrenilmesi zor bir dil olmasına rağmen romantik dil olduğu: "öğrenilmesi zor almancayla benzerlik gösteren dil. aynı zamanda en zor günlerin en güzel aşk şarkılarının dili” [İo1- soosyopat, 25.12.2009], aslında çok da zor bir dil olmadığı ancak fill çekimlerinin bu dili zorlaştırdı̆̆ı: “@3 dişilere la deniyo @2

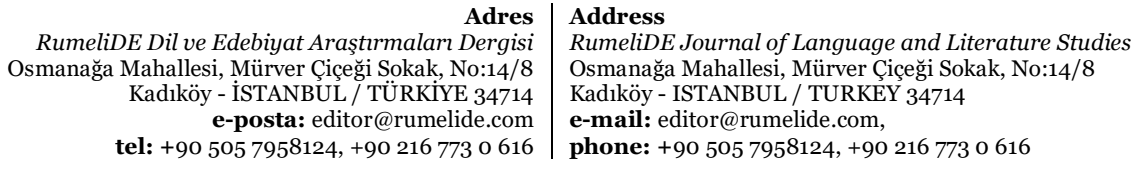


la dil o kadar zor değil sadece filler biraz deişiyo o zorluyo o kadar” [i்34-susisesindebalik, 25.09.2011], yazılışı ile okunuşu arasında farklılıklara rağmen sevilen bir dil olduğu: "yazılışıyla okunuşu arasında dağlarca fark olan zütü başı ayrı oynayan dil. ama çok güzel bi dil ben de öğrenmeye başladım amk bakalım seviye kaça kadar çıkıcam” [İ55-cccisterikizmirliccc, 17.03.2013], sözlük yazarının yetiştiği bölgenin gırtlak yapısıyla Fransızcanın gırtlak yapısının birbirine çok benzediği ve bu yüzden telaffuzunda zorlanmadığını ancak bazı gramer kurallarını anlamakta zorlandığını:

\begin{abstract}
“şaka maka cümle kurmaya başladım amk. anadolu çocuğu olduğum için gırtlakta alışık. telafuzlarda hiç zorlanmıyorum. tek şimdilerde problemim ceci ve ce arasında ki farkı hala kavrayamamış olmam.. atıyorum mesela şu iki bina beyaz renkli demek istiyorum, ceci sont des deux immeubles blancs. ama fransızların bazıları yukarıda ki cümlende hata yok derken bazıları ise daha farklı kuruyor. özellikle cezayir ve tunuslular. dıbına koyim bu sömürgelerden adam olmaz. 20 yaşındayız daha amk. 3 . dilimizi öğreniyoruz şurda! bu kadar sık boğaz etmeye ne gerek var! [í61- ayvilteykyuurvirginity, 17.05.2013].
\end{abstract}

ve son olarak da Fransızcanın sesletiminin oldukça zor olduğu ancak farklı bir Latin dili bilindiği takdirde bu dili öğrenmenin kolaylaştığı, yazarın Fransızca ile İspanyolca arasında karşılaştırma yaparak İspanyolcanın dünya genelinde Fransızcadan daha çok konuşulduğunu, yazılışı ve okunuşu arasında fark olmadığı, telaffuzun kolay olduğunu ve bu dil bilindiği takdirde Fransızca öğrenmenin kolay olacağı dile getirilmektedir:

\begin{abstract}
"hayatında yabancı dil bilmeyen adam uzak dursun. fransızcanın en zor kısmı telaffuzdur. çok ağır bir dil. bunun yerine size ispanyolcayı öneririm. neden mi? 1) 500 milyondan fazla insan konuşuyor. ingilizceden fazla konuşulan dil diyenlerde var. 2) 33 ülkenin resmi dili. 3) türkçe bilen birisine ispanyolca metin verin ufak tefek hatalarla doğru bir şekilde o metni okuyabilir. evet yazılan kelimeler türkçe olarak okunuyor. 4) aksanı ne arapça gibi kalın ne ingilizce gibi ince aynı bizim dilimiz gibi orta halli. buda demektir ki telaffuzu kolay. 5) ingilizce gibi kelimelerin yarış yutulmuyor tam tersi her kelimeyi söylüyorsun buda anlamayı kolaylaştırıyor. kısaca bir türkün öğrenebileceği en ideal dildir. bunun yanında dünyanın en ciksi dilidir, aşkın dilide diyebiliriz. aslında fransızca ile arasında çok fazla kulak farkı yok sonuçta ikiside latin dili. bunu öğrenin ardından italyanca ve fransızca öğrenmeniz kolaylaşacak. hasta la vista (görüşmek üzere) okunuşu ise yazıldığ 1 gibi adios misal http://www.youtube.com/watch?v=X8s-2_bsJsU evet yazıldığı gibi okunuyor” [ذ్I74-pekis sinici, 07.06.2014].
\end{abstract}

5. İronik Söylemler: İronik söylemler teması da yine TDK Sözlüğü (2021)'nün: "söylenen sözün tersini kastederek kişiyle veya olayla alay etme” tanımı esas alınarak oluşturulmuştur. Bu bağlamda derlemde sözlük yazarlarının Fransızcaya ilişkin ironik, bir başka deyişle alaycı görüşlerin yer aldığı toplamda 2 (iki) giriş tespit edilmiştir. Her 2 (iki) girdide de Fransızcanın telaffuzuyla alay edildiği anlaşılmaktadır: Örneğin İo2 kodlu girdide yazar, Fransızcada en çok telaffuz edilen "lö"(le) tanımlığını alaya aldığı: "bir franszz kızına lö lö lö çekmeye yetecek kadar hakimi olduğum dil” [tasakli soda, 25.12.2009] görülürken, bir diğer girdide ise yazar " $r$ " harfini söyleyemediği için Fransızcanın sesletiminde ne denli "başarılı olduğunu" ironik bir dille ifade etmektedir: "Telaffuz kısmını müthiş yapıyorum, $r$ harfini söyleyemiyorum mesela hirtlak zaten var" [İ49-capslikonu, 12.10.2012].

6. Cinsellĭği Çăgrrşttran Dil Olduğuna Dair Söylemler: Derlemde yazarlarının Fransızcanın cinselliği çağrıştıran bir dil olması şeklindeki 2 (iki) söylemi de dikkate değerdir. Bu denli söylemlerinde yazarlar, Fransızcada kimi kelimelerinin okunuşlarını Türkçedeki bir takım seslerle bağdaştırarak cinselliği çağrıştırdığını dile getirmişlerdir. Öyle ki İ11 kodlu girdinin yazarı : “ön sevişme dili aq gibiş dili için" [ortabacak, 31.07.2010] gibi bir yorumda bulunurken, İ14 kodlu girdinin yazarı ise: "benm knştuğm bi dil am züt meme" [kisish, 21.09.2010] şeklinde bir benzetmede bulunmuştur. Söylemlerden de anlaşılacağı üzere yazarlar Fransızcanın kimi sesletimsel özellikleriyle yine Türkçe kimi argo ya da

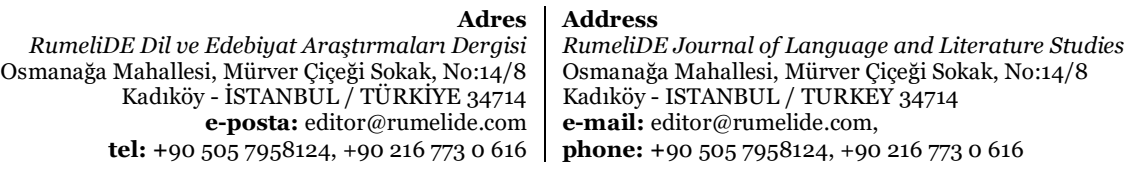


küfürler ile benzerlikler kurarak bu dilin kendileri için cinselliği çağrıştırdı̆̆ına dair söylemlerde bulunmuşlardır.

7. Dĭ̆ erleri: Nitekim yukarıda da belirtildiği gibi derlemdeki toplam 95 girdiden 13’nünün araştırmanın amacıyla doğrudan herhangi bir bağlantısının olmadığı belirlenmiştir. Böylelikle çözümleme aşamasında bu türden söylemler "diğerleri” (Tablo 1) şeklinde başlıklandırılarak çözümlemeye dâhil edilmemiştir. Şöyle ki: "sular seller gibi biliormmmmmmm” [İo8- suzan, 25.05.2010] ve "ben çok iyi fransızca konuşurum bakn; indila" [İ79- akisearu, 08.08.2014] gibi söylemlerinde yazarların tam olarak neyi ifade etmek istedikleri, yani Fransızcayı gerçekten konuşabildiklerine dair herhangi bir netlik yoktur. Diğer yandan: "en az türkçe kadar iyi bildigim dil sil

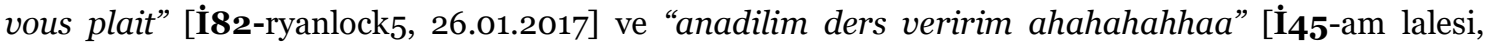
14.06.2012] söylemlerinde de yazarlarının Fransızcayı kendi anadilleri kadar bildiklerine dair bir kesinlik yoktur. Bu türden anlam belirsizlikleri olan girdiler (söylemler) çalışmadan sağlıklı sonuçlar elde edilmesine olanak tanımayacağı için çözümlemeye dâhil edilmemiştir.

\section{Sonuc}

Orta Çağdan başlayrak 20. yüzyıl başlarına kadar pekçok alanda Türkler için oldukça önem arz eden bir dil olma özelliğini koruyan Fransızca, II. Dünya Savaşı sonrası Soğuk Savaş Dönemi (1948-1989) olarak adlandırılan süreçte Amerika Birleşik Devletleri'nin dünya genelinde siyasi, ekonomik ve askeri alanlarda süper güç haline gelmesiyle yerini İngilizceye bırakır. Günümüz itibariyle özellikle eğitim sistemimiz içerisinde İnglizce ve Almancanın ardından üçüncü bir yabancı dil olarak kendisine yer edinmiş olsa da yukarıda da vurgulandığı gibi Türk tarihi ve modernleşmesi bakımından ayrı bir yere yere ve öneme sahiptir. Böylelikle, yüzyıllardır Fransız dili ve kültürüyle etkileşim halinde olan Türk insanının da bu dile ve onun kimi özelliklerine değin bu süreçte doğru ya da yanlış pekçok görüş, düşünce ve algısı ortaya çıkmıştır. Bu çalışmada bir olgubilim deseni çerçevesinde Türkiye'nin en etkileşimli sanal alanlarından biri olarak bilinen İnci Sözlük platformu yazarlarının Fransızcaya dair duygu, düşünce ve görüşlerinin söylem çözümlemesi aracılığıyla değerlendirilmesi amaçlanmıştır. Öncelikle sözlükteki "Fransızca" başlıklı girdilerin tamamı derlenerek bir bütünce oluşturulmuş, ardından bütünceki girdiler tek tek Herring (2004)'in önerdiği söylem çözümlemesi çerçevesinde çözümlenerek yorumlanmıştır.

Çözümlemeler neticesinde sözlük yazarlarının Fransızcaya dair en çok yansız yorumlarda bulundukları sonucuna varılmıştır. Böylelikle girdi (söylem)'lerden yazarların basit, orta ya da ileri seviyede Fransızca bildikleri ve konuştukları, Fransızcanın öğrenilmek istenen dillerden biri olduğu, bunun yanısıra kimi sözlük kullanıcılarının Fransızca öğrenmek ya da bu dili geliştirmek için diğer sözlük yazarlardan tavsiye istedikleri, Fransızca bilen yazarların da bu konularda onlara destek olabileceklerini ifade eden türden söylemlere (yorumlara) rastlanmıştır. Kimi sözlük yazarının bu dilin öğrenilmesi gereken önemli bir dil olması yönündeki görüşleri, Demiryürek (2013: 131)'in de vurguladığı gibi; "Fransızca hem edebiyat açısından hem de bilim ve fen açllarından ayrı bir öneme sahiptir. Fen bakımından Fransızlar Almanya ve İngiltere kadar gelişmiş olmasa da onlardan çok da aşağıda değildirler. Ayrıca Fransızcanın uluslararası diplomasi/siyaset dili olarak kabul edilmiş olması bu dilin önemini daha da arttırmaktadır. $\mathrm{Bu}$ nedenle Fransızca öğrenilmesi gerekli bir yabancı dildir” düşüncesi ile örtüştüğü söylenebilir. Bununla birlikte, kimi sözlük yazarlarının da Fransızca ile ilgili olumsuz yorumlarda bulunduğu anlaşılmaktadır. Söz konusu yazarlar, Fransızcanın öğrenilmesinin oldukça zor olduğunu, hatta kaba ve itici bir dil olduğunu ve bu dili sevmediklerini ifade etmişlerdir. Diğer yandan kimi yazarların da benzer şekilde; Fransızcanın sesletiminin oldukça zor olduğunu, harflerin yazıldığı gibi okunmadığını ve fiil

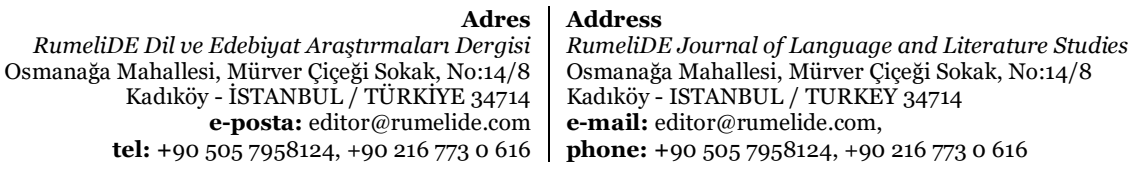


çekim kurallarının zor olduğu yönünde söylemlerde bulundukları görülmektedir. Ancak bu konuda her ne kadar kimi sözlük yazarlarının olumsuz yönde bilgi ve düşünceleri olsa da Kuşçu (2018: 356)'nun da vurguladığı gibi Fransızcada harfler yazıldığı gibi okunmaz ise de sözcüklerin sesletimi belli kurallar çerçevesinde gerçekleştirilir. Diğer bir ifadeyle, bu dildeki sesletim biçimlerinin neredeyse tamamı istinasız bir kurala bağlıdır. Yabancı dil olarak Fransızca öğrenmek isteyenlere, bu dilin en büyük zorluklardan birinin sesletimi olduğu telkin edilse de aslında bu özelliğin matemetiksel bir örgü içinde gerçekleştiği bilinmelidir. Bu bağlamda son olarak, yine Fransızca dilbilgisi kurallarının belirgin olmayıp oldukça zor olduğu dile getirilse de Abusharifa (2016: 5) ya göre bu durum Fransızcada farklı aksanların kullanılması neticesinde bunlara değin ortaya çıkan kimi düzensizliklerden kaynaklanmaktadır. Öyle ki, söz konsu düzensizlikler özellikle yazılı Fransızcada oldukça fazla hataya neden olmakta, bu da öğrenmeme sürecini zorlaştırmaktadır.

Diğer yandan, İnci Sözlük yazarlarının Fransız diline dair olumlu söylemlerde bulundukları girdiler de saptanmıştır. Bu türden söylemlerinde yazarlar Fransızcayı neden sevdiklerini ve öğrenmek istediklerini; bu dilin kulağa hoş gelmesi, dinlemesinin keyifli olması, müziğin dili olması, çekici olması ve öğrenmesinin keyifli olması gibi farklı söylemlerle dile getirmektedirler. Benzer şekilde Henry (2019) de Fransızcanın her zaman insanlar için cezbedici bir yanı olduğunu ifade etmektedir: "Fransız dilinin güzelliği oldukça basit bir nedene dayanır. $\mathrm{O}$ da bu dilin prozodisidir. Bütün tarih boyunca Fransızca en melodik ve en zarif anlamda kendini var etmiştir." Yine bazı yazarların ise, Fransızcayı romantik, kibar, karizmatik, elit ve aksanının güzel bir dil olması dolayısıyla sevdikleri sonucuna varılmıştır. Öyle ki Aurélie (2016) de Fransızcanın romantizmin ve aşkın dili olduğuna vurgu yapmaktadır: "Dönemin romanları, oyunları ve şiirleri çoğunlukla aşk hakkındaydı ve yıllar içinde romantizmin kült eserleri haline geldi. Nitekim Fransız yazarları zamanın kötü hissini benzersiz şekilde ifade ettiler. Fransızca hızla duyguların ve tutkuların dili haline geldi, 21. yüzyılda bu durum geçerliliğ̈ini sürdürmektedir."

Girdelerde sözlük yazarlarının Fransızcaya dair öne çıkan bir diğer söylem türü ise Fransızcanın aynı anda hem olumsuz hem de olumlu olarak algılandığı söylemlerdir. Bu bağlamda, Fransızcanın öğrenilmesi zor olmasına rağmen romantik bir dil olması, Fransızcanın öğrenilmesi kolay olmasına rağmen fiillerin zor olması, yazıldığı gibi okunmamasına rağmen güzel bir dil olması şeklinde tek bir söylemde yazardan yazara değişebilien göreceli aynı anda hem olumsuz ve hem de olumlu olabilen ya da tam tersi görüşler dile getirilmiştir.

Sayıca çok az olsalar da derlemde kimi girdilerde Fransızcanın sesletiminden dolayı alaya alındığı ve cinselliği çağrıştıran bir dil olduğuna dair söylemlere ulaşılmıştır. Söz konusu girdilerdeki alaycı (ironik), küfürlü ve argo söylemlerin Fransızcanın sesletim özelliğinden, özellikle kimi sözcüklerin gırtlak sesletiminden kaynaklandığı anlaşılmaktadır. Fransızcada bazı kelimeler okunuşlarından dolayı sözlük yazarlarına cinselliği çağrıştırdığı düşünülse de ABD merkezli Hotels.com adlı internet sitesi tarafından düzenlenen 8 bin gezginin katıldığı dünya çapındaki ankette Fransızca en seksi lisan olarak seçildiğı görülmektedir (Dış Haberler Servisi-Milliyet, 2013).

Genel olarak bakıldığında İnci Sözlük yazarlarının Fransızcaya dair algılarının ağırlıklı olarak kendi deneyimlerinden kaynaklandığı görülmektedir. Şöyle ki; kimi sözlük yazarı Fransızcanın dünyada en önemli dillerden birisi olması dolayısıyla öğrenilmesi gerektiğini savunurken, bir diğeri ise bu dilin itici, zor ya da çabuk unutulduğu şeklinde söylemde bulunmaktadır. Diğer yandan kimi katılımcılar Fransızcanın kendine özgü sesletim yapısıyla alay ederken, kimileri de bazı kelimelerindeki okunuşları Türkçe ile bağdaştırarak Fransızcanın cinselliği çağrıştırdığını dile getirmektedir. Fransızcanın yapısına dair kimi özellikleri göz önünde bulundurulduğunda bütün bu söylemlerin kısmi doğruluk payı olsa da

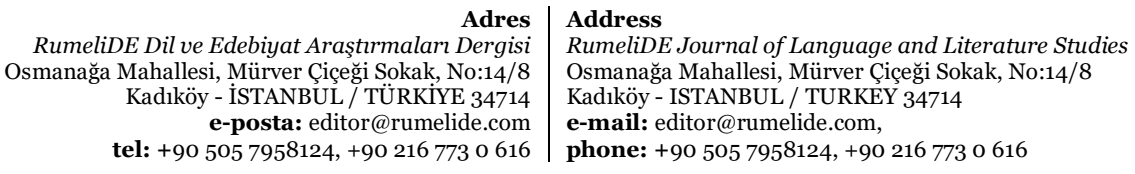


birçok sözlük yazarının herhangi bir eğitim ve deneyime sahip olmaksızın kulaktan dolma bilgilerle bu dil hakkında yorumlarda bulundukları açıktır.

Son olarak, yaklaşık geçmiş iki yüzyıl boyunca Türkler için siyasi, sosyal ve kültürel anlamda oldukça önem arz eden, bir başka deyişle Türk modernleşmesi ve Batılılaşma herakatına aracılık eden Fransızca bugün eski görkemini ve önemini yitirmiş gibi görülmektedir. Ancak, günümüzde özellikle gençler tarafından bilinen ve oldukça sık kullanılan bir iletişim/ etkileşim platformu olan İnci Sözlük katılımcıları nezdinde, daha doğrusu onların bu dile değin söylemlerinden hareketle yapılan çözümlemeler neticesinde Fransızcanın Türkler tarafından hala sevilen ve önemsenen bir yabancı dil olduğu sonucu ortaya çıkmaktadır. Bu sebeple, Fransızcanın tekrar eski geçerliliğini kazanması devletlerarası ilişkilere bağlıdır. Bunun yanı sıra bilişim çağı olarak adlandırılan günümüz dünyasında bir ulusun evrensel düzeyde gelişimi, o ulusun eğitim, sanat, kültür ve siyaset gibi alanlarda diğer uluslarla olan etkileşimiyle doğrudan ilintilidir. Dolayısıyla, bilimsel ve kültürel iletişimde çok dilliliğe giden bugünün dünyasında (Helsinki Initiative, 2019) hak ettiğimiz yeri almak ve Ulu Önder Mustafa Kemal Atatürk'ün de işaret ettiği gibi çağdaş uygarlık seviyesine ulaşmak için eğitim sistemimizde sadece tek bir yabancı dilin - özellikle İngilizcenin- öğretimine değil başka yabancı dillerin öğretimine de gereken önem verilmelidir.

\section{Kaynakça}

Abusharifa, Y. (2011). Les difficultés spécifiques du français pour les élèves palestiniens (Mémoire de Master 1 en Linguistique et Didactique des Langues-FLE). Université de Rennes 2, France. http://dx.doi.org/10.13140/RG.2.1.2823.7843

Aurélie. (le 18 novembre 2016). Pourquoi la langue de Molière est la plus romantique du monde ? superprof (blog). https://www.superprof.fr/blog/romantisme-langue-francaise/

Avcı, M. (2020). Mustafa Kemal Atatürk’ün yabanci dil bilgisi ve Türkçeye kazandirdiği eserler. Kurıkkale Üniversitesi Sosyal Bilimler Dergisi, 10(2), 519-548. https://dergipark.org.tr/tr/pub/kusbd/issue/56190/729433

Baron, N. S. (1984). Computer mediated communication as a force in language change. Visible Language, 18(2), 118-141. https://s3-us-west2.amazonaws.com/visiblelanguage/pdf/18.2/computer-mediated-communication-as-a-forcein-language-change.pdf

Binark, M. F. ve Löker, K. (2011). Sivil toplum örgütleri için bilişim rehberi. Ankara: Sivil Toplum Geliştirme Merkezi. https://ekitap.alternatifbilisim.org/pdf/stkler-icin-bilisim-rehberi.pdf

Bozkurt, A., \& Biroğul, S. (2012). Bilgiyi, "kümülatif bir biçimde oluşturup paylaşan" siteler: Etkileşimli sözlükler. Bilişim: Aylık Bilişim Kültürü Dergisi, 40(140), 16-19. http://www.bilisimdergisi.org.tr/bilisim-dergisi-sayilari/s140.pdf

Çeçen, A. F. (2019). Medeniyetler çatışması bağlamında yeni medya ortamında siyasi parti ve ideolojik medyanm söylem analizi (Doktora Tezi). İstanbul Üniversitesi Sosyal Bilimler Enstitüsü. http://nek.istanbul.edu.tr:4444/ekos/TEZ/ETooo140.pdf

Çomu, T. (2012). Video paylaşım ağlarında nefret söylemi: Youtube örneği (Yüksek Lisans Tezi). Ankara Üniversitesi Sosyal Bilimler Enstitüsü.

https://dspace.ankara.edu.tr/xmlui/handle/20.500.12575/31698

De Wever, B., Schellens, T., Valcke, M., \& Van Keer, H. (2006). Content analysis schemes toanalyze transcripts of online asynchronous discussion groups: A review. Computers and Education, 46(1), 6-28. http://dx.doi.org/10.1016/j.compedu.2005.04.005

Demiryürek, M. (2013). Türkiye'de yabancı dil olarak Fransızca öğretiminin tarihi gelişimi üzerine bir değerlendirme (1891- 1928). Hacettepe Üniversitesi Ĕ̆itim Fakültesi Dergisi, 28(1), 130-140. https://dergipark.org.tr/tr/pub/hunefd/issue/7789/101834

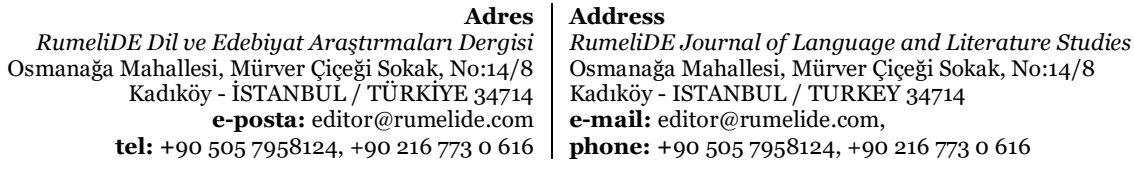


Dış Haberler Servisi (01.11.2013). En seksi dil Fransızca. Milliyet. https://www.milliyet.com.tr/gundem/en-seksi-dil-fransizca-1785409

Dilmen, N. E. (2007). Yeni medya kavramı çerçevesinde İnternet günlükleri-bloglar ve gazeteciliğe yansımaları. Marmara İletişim Dergisi, 12(12), 113-122. https://dergipark.org.tr/tr/download/article-file/2936

Dondurucu, Z. B. (2017). The analysis of messages which include hate speech for women in Inci Sozluk. In M. Demir \& Ş. Şen Demir (Eds.), The Proceedings \& Abstracts of ICSSER- 3rd International Conference on Social Sciences and Education Research (p. 226). International Center of Social Sciences \& Education Research. https://dergipark.org.tr/tr/download/journal-file/8533

Dondurucu, Z. B. (2018). Yeni medyada cinsel kimlik temelli nefret söylemi İnci Sözlük örneği. Gümüşhane Üniversitesi İletişim Fakültesi Elektronik Dergisi, 6(2), 1376-1405. https://dergipark.org.tr/tr/download/article-file/558844

Gökmen, A. (2017). The state of French on the territory of Turkey: From traditional to globalism. Türk \& İslam Dünyası Sosyal Arassttrmalar Dergisi, 4(13), 1-18. http://dx.doi.org/10.16989/TIDSAD.1336

Gürel, E., Yakın, M. (2007). Ekşi Sözlük: Postmodern elektronik kültür. Selçuk İletişim Dergisi, 4(4), 203-219. https://dergipark.org.tr/tr/pub/josc/issue/19014/200751

Güzel, B. (2015). Fransızcanın gelişimi ve Fransızca öğretiminde motivasyon arttırıcı bir yöntem: Fransizcadan Türkçeye geçen kelimeler. International Journal of Languages' Education and Teaching, (UDES-2015), 317-327. https://docplayer.biz.tr/17814574-International-journal-oflanguages-education-and-teaching.html

Helsinki Initiative (2019). Helsinki Initiative on Multilingualism in Scholarly Communication. Helsinki: Federation of Finnish Learned Societies, Committee for Public Information, Finnish Association for Scholarly Publishing, Universities Norway \& European Network for Research Evaluation in the Social Sciences and the Humanities. https://doi.org/10.6084/m9.figshare.7887059.

Henry, L. (le 14 octobre 2019). Pourquoi le français est la plus belle langue du monde. Quora : un lieu pour partager le savoir et mieux comprendre le monde. https://fr.quora.com/Pourquoi-lefrançais-est-la-plus-belle-langue-du-monde-1

Herring, S. C. (2004). Computer-Mediated Discourse Analysis: An approach to researching online behavior. In S. A. Barab, R. Kling, \& J. H. Gray (Eds.), Designing for virtual communities in the service of learning (pp. 338-376). Cambridge University Press. https://doi.org/10.1017/CBO9780511805080.016

İnci Sözlük. (25.12.2020). İnci Sözlük. Wikipedia. https://tr.wikipedia.org/wiki/İnci_Sözlük

Kartal, E. (2017). Türkiye'deki üniversitelerin Fransızca programları ve bu programlarda yapılan akademik çalışmalar üzerine bir değerlendirme. Frankofoni, (31), 367-380. https://uludag.academia.edu/erdogan_kartal

Kuşçu, E. (2018). Üniversite öğrencilerinin ikinci yabancı dil olarak Fransızca öğrenme profilleri: Pamukkale Üniversitesi Eğitim Fakültesi ve Fen-Edebiyat Fakültesi Örneği. Kastamonu Eğitim Dergisi, 26(1), 1-9. https://dergipark.org.tr/en/download/article-file/366156

Marra, R. M., Moore J. L. \& Klimczak A. K. (2004). Content analysis of online discussion forums: A comparative analysis of protocols. Educational Technology Research and Development, 52(2), 23-40. https://link.springer.com/content/pdf/10.1007/BF02504837.pdf

Mazur, J. M. (2004). Conversation analysis for educational technologists: theoretical and methodological issues for researching the structures, processes and meaning of on-line talk. In D. H. Jonassen (Ed.), Handbook for Research in Educational Communications and Technology (pp. 1073-1098) Mahwah, NJ: Lawrence Erlbaum Associates. https://members.aect.org/edtech/40.pdf

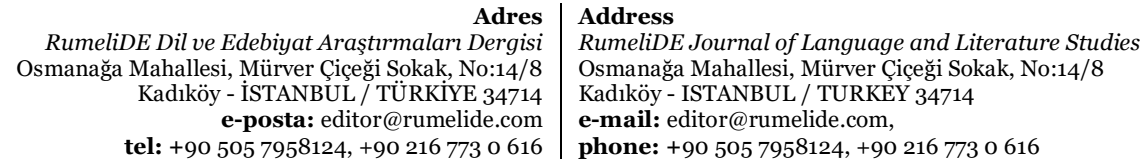


Merriam, S.B. (2018). Nitel araştırma desen, uygulama ve uygulama için bir rehber (Çev. S. Turan). Ankara: Nobel Akademik Yayıncllı.

Miles, M, B., \& Huberman, A. M. (1994). Qualitative data analysis: An expanded Sourcebook. (2nd edition). Thousand Oaks, CA: Sage. https://vivauniversity.files.wordpress.com/2013/11/milesandhuberman1994.pdf

Özdemir, M. (2010). Nitel veri analizi: Sosyal bilimlerde yöntembilim sorunsalı üzerine bir çalışma. Eskişehir Osmangazi Üniversitesi Sosyal Bilimler Dergisi, 11(1), 323-343. https://dergipark.org.tr/tr/pub/ogusbd/issue/10997/131612

Özer, K (Ed.). (2012). İnci Sözlük'ün en eski yöneticisi Gürkan Dündar: İnternet, ansiklopedilerden uzaklaşmamızı ve bir tık ile birçok bilgiye ulaşmamızı sağlıyor (Röportaj). Bilişim: Aylık Biliş̧im Kültürü Dergisi, 40(140), 36-45. http://www.bilisimdergisi.org.tr/bilisim-dergisisayilari/s140.pdf

Sağır, A. (2012). Küresel dünyanın yeni sosyal paylaşım mekânları: İnternet sözlüklerinin sosyolojik çözümlemesi. Sosyoloji Dergisi, (26), 1-31. https://karabuk.academia.edu/AdemSağıroğlu

Sezgintürk, P. (2020). Kolektif hafıza bağlamında Fransız dili ve kültürünün Gazi Mustafa Kemal Atatürk’ün entelektüel ve devrimci kişiliğinin oluşumuna etkisi. Söylem Fïloloji Dergisi, 5(2), 438-458. http://dx.doi.org/10.29110/soylemdergi.757284

Söğüt, F. (2020). İnternet sözlüklerinde mekânsal ötekileştirme üzerine bir araştırma: Ekşi Sözlük'te Esenyurt başlı̆̆ örneği. Gümüşhane Üniversitesi İletişim Fakültesi Elektronik Dergisi, 8(1), 4568. https://dergipark.org.tr/tr/download/article-file/1025434

Türk Dil Kurumu. (2021). Türk Dil Kurmu Sözlük. https://sozluk.gov.tr/

Türk, G. D., \& Tugen, B. (2016). Dijital cemaatler ve postmodern kabile örneği: İnci Sözlük. M. Akgül, U. Çağlayan, E. Derman, A. Özgit, A. Koltuksuz ve M. Komesli (Ed.), 19. Türkiye'de İnternet Konferansı Bildiriler Kitabı içinde (ss.73-78). İnternet Teknolojileri Derneği (İNETD). http://inet-tr.org.tr/inetconf19/kitap/_inet14.pdf

Uçkan, Ö. (2012). Sözlükler: Türkiye İnternet kültürünün vazgeçilmezi... Bilişim: Ayllk Bilişim Kültürü Dergisi, 40(140), 22-27. http://www.bilisimdergisi.org.tr/bilisim-dergisi-sayilari/s140.pdf

Wilson, S.M., \& Peterson, L. C. (2002). The anthropology of online communities. Annual Review of Anthropology, (31), 449-467. https://doi.org/10.1146/annurev.anthro.31.040402.08543

Yazıcı, T. (2016). Yeni medyanın nefret dili: Suriyeli mültecilerle ilgili Ekşi Sözlük örneği. Global Media Journal TR Edition, 7(13), 115-136. https://globalmediajournaltr.yeditepe.edu.tr/sites/default/files/T\%C3\%BClay\%20YAZICI.pdf

Yılancioğlu, S. (2014). Les intellectuelles ottomanes et la langue française. Revue Roumaine d'Études Francophones: La Francohonie dans les Balkans, (6) 50-62. http://arduf.ro/wpcontent/uploads/2021/o3/Yilancioglu-2.pdf

Yıldırım, O., \& Başer E. (2016). İnternetin girişimciliği kapsamında değişen enformasyon siteleri üzerine bir değerlendirme. Global Media Journal TR Edition, 6(12), 172-200. https://globalmediajournaltr.yeditepe.edu.tr/sites/default/files/Ozan\%2oYILDIRIM\%20\%26\% 20Emrah\%20BA\%C5\%9EER.pdf

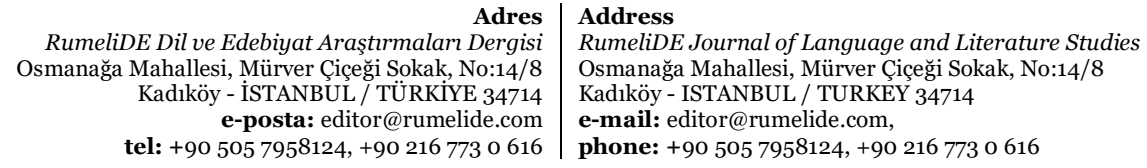

